\title{
DISCUSSION
}

\section{LANGUAGE AND GENDER STUDIES: PAST AND CURRENT APPROACHES AND DEBATES}

\author{
Nguyen Thi Thu Ha* \\ Faculty of Linguistics and Cultures of English-speaking Countries, \\ VNU University of Languages and International Studies, \\ Pham Van Dong, Cau Giay, Hanoi, Vietnam
}

Received 27 December 2016

Revised 06 November 2017; Accepted 24 November 2017 \begin{abstract}
researchers in the field of the updated foci in literature. and sexuality

\section{Introduction}

Language and gender as a domain of linguistics emerged in the 1970s and has been growing vigourously up to now. Research in this domain has been influenced by both theories and approaches in linguistics as well as those in social studies and political movements such as feminism, gender study, philosophy, media studies and so on. Because studies in this domain are diverse in political and theoretical stance, a review of those studies is necessary to offer interested researchers a map of existing debates from which they can launch their own novice arguments.
\end{abstract}

Abstract: This study looks at the different approaches in language and gender research since its emergence in the early 1970s. These approaches, namely the dominance, the difference and the postmodernist approach, are reviewed in a chronological order together with sample studies reflecting the tenets of each approach. A comparison across the approaches is also provided to offer profound understanding of the approaches. Current trends in language and gender studies are also highlighted to inform potential

Keywords: language and gender, gender difference, gender dominance, post-structuralism, language

\section{Methodology}

This is a secondary research which aims to chronologically review studies in language and gender as a domain of linguistics.

${ }^{*}$ Tel.: 84-903266696

Email: hantt@vnu.edu.vn
The methods of study include researching published sources such as books, monographs, journals and categorizing studies under different approaches. The study also tries to describe the main tenets and characteristics of different approaches, then compare and contrast between approaches. The study also consults and bases itself on existing studies on the same topic and offer critical comments where possible. Latest studies in language and gender presented at IGALA 2016 (International Gender and Language Association) are also reviewed to show the directions in which research in the domain is heading.

\section{Findings}

3.1. The starting point and the dominance approach

Research in language and gender emerged in the 1970s with Lakoff's 'Language and women's place'(Lakoff, 1975). This study was 
seen as the starting point of different debates on how men and women differed in their language use. In explaining the differences that they found in men and women's language use, those studies fall into two approaches: the dominance and the difference approach.

In the dominance approach, some authors argued that differences between men and women's speech arose because of male dominance over women and persisted in order to keep women subordinate to men. This trend of studies was known as (male) dominance approach with many noted names such as Zimmerman and West (1975), Eakins and Eakins, Crosby and Nyquist, Mulac et al, and Fishman (see Coates, 1998). They analyzed conversations in college communities, staff meetings, and conversations between husbands and wives, or they considered the length of time it took men and women to describe pictures, etc. Their findings included different styles of using language, differences in turn taking, length of speech, word use, tag questions, hedges, etc. (see figure 1).
Studies in language as a system even pointed out that language was created by men in order to sustain a patriarchal order; hence, English is sexist by nature (Spender, 1980). If language can be shown to influence or determine thought, then sexist language will influence speakers in the direction of sexist thought. Changing sexist language will change sexist attitudes and will raise awareness about sexist assumptions. This understanding led to language reform or political correctness from which many anti-sexist terms were introduced to replace their counter-parts such as $M s$, spokesperson, chairperson, etc. However, this movement soon experienced a backlash because theorists realized that removing sexist language did not entail elimination of gender discrimination; rather, sexist assumptions were embodied by linguistic choices made by language users (Cameron, 1992:18).

To offer a clearer view on how studies in this approach were carried out, the study includes in this section a summary of two typical studies focusing on the differences

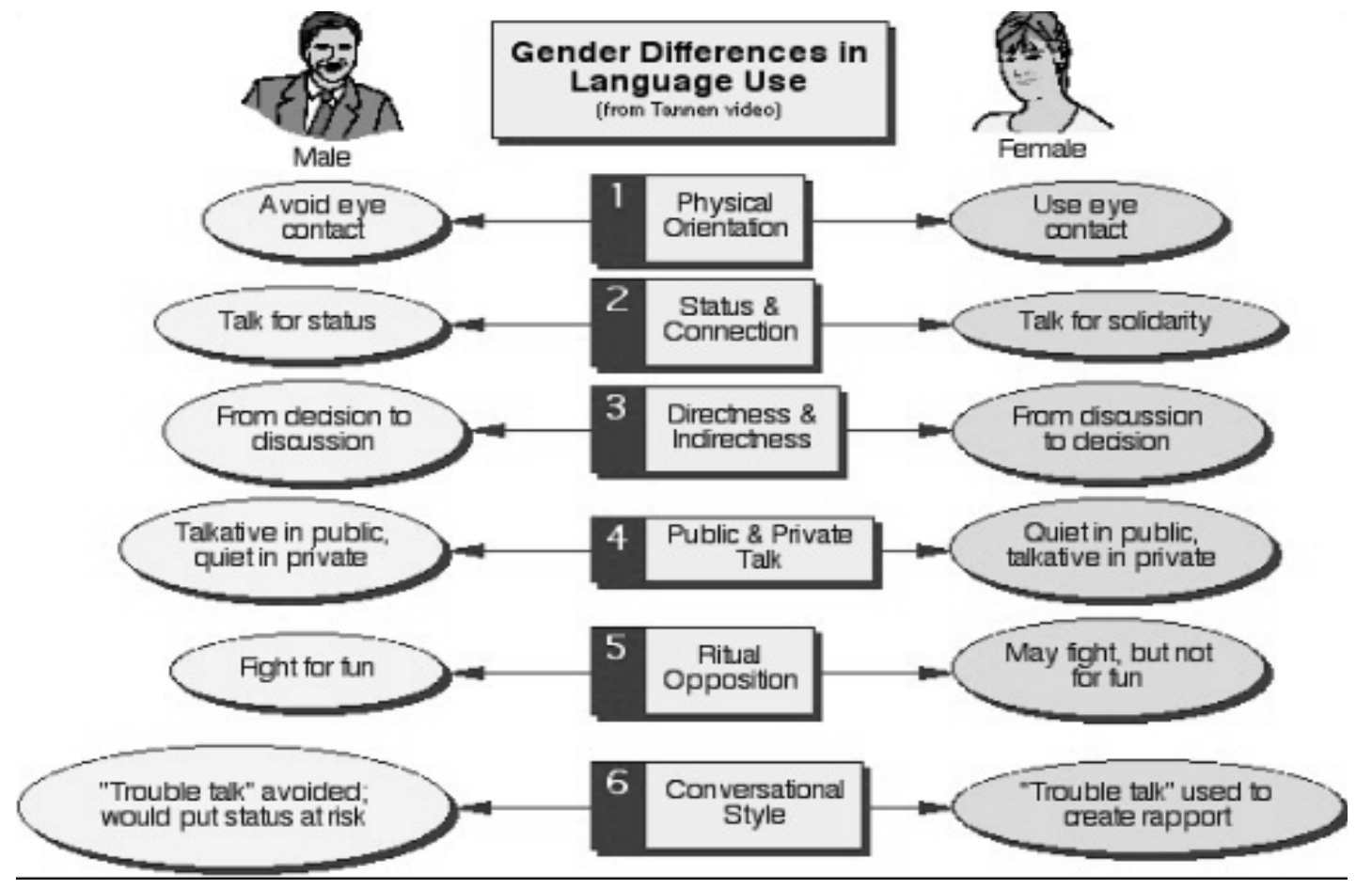

Figure 1. Gender differences in language use (Tannen, 1985) 
between men and women's language use. As a first example, When the doctor is a lady, by West (1984), was a conversational analysis of doctor-patient talks. The study found that male doctor interrupted patients disproportionately, while female doctors were interrupted by their patients as much as or even more than the doctors did. This suggested that gender outweighed social status in this case. These results were supported by Woods (1989), who found that in the work setting, gender was more important than status in predicting linguistic behavior, with female bosses regularly interrupted by male subordinates. Another study in this approach was DeFrancisco (1991): The Sounds of Silence: How Men Silence Women in Marital Relations. The author focused on non-cooperation in interaction in domestic environments. She asked seven married couples to record themselves at home for a week or more, then she interviewed the participants. She found out that women talked more than men and introduced more topics: this was associated with dominance. However, women were less successful than men in getting their topics accepted. Men used various non-cooperative strategies to control conversations, for example, no response, interruption, and silence. From these findings, the author proposed that men had the power to establish the norms of everyday conversation in the home, and women had to adapt to these norms. Various studies in this approach can be found in Coates (1998).

\subsection{The difference approach}

Some other researchers later saw the difference between men and women in speech as the result of the fundamental differences in their relation to their language, perhaps due to the different socialization and experiences early on (Tannen, 1994). This was known as (cultural) difference approach, whose followers were mostly influenced by the Western European feminist idea (Beasley,
1999:16) that men and women just were different, which entailed a concern of separatism, a deliberate choice by women to remain separate from men in some way. Though limited in number, studies in this approach gained huge readership and many critics; typical studies included A cultural approach to Male-Female Miscommunication by Daniel Maltz and Ruth Borker's (see Coates,1998), That's not what I mean (Tannen, 1986), You just don't understand: Men and women in conversation (Tannen, 1990) and Men are from Mars, women are from Venus (Gray, 1992). In That's not what I mean, Tannen (1986) analyzed fictions, transcription from other research and conversations recorded by herself and her friends. She concluded that women and men belong to different sub-cultures, and interactional problems between men and women are crosscultural miscommunication.

According to Cameron (1992), as quoted in Sunderland (2004), both cultural difference and male dominance approaches represented different moments in feminism. Dominance was the moment of feminist outrage, of bearing witness to oppression in all aspects of women's lives, while difference was the moment of feminist celebration, reclaiming and revaluing women's distinctive cultural traditions. Both the dominance and difference approaches drew on essentialist notions of gender, seeing gender as naturally determined, stable and pre-existing discourse.

The two approaches were later criticized on many counts. First, language reform (political correctness) was superficial and trivial (Sunderland, 2004). Removing sexist language did not entail elimination of gender discrimination. We need to challenge the particular 'discourse practices' in which sexist assumptions are embodied by linguistic choices rather than to keep on asserting 'language' was sexist in itself (Cameron, 
1992). Second, the methods used were mainly introspection and researchers' or native speakers' intuition so they were not systematic and reliable. Third, the two approaches see men and women as homogenous groups and they cannot successfully separate gender from other social variables such as power, age, context, etc. Fourth, there seems to be a simple mapping from linguistic forms and functions (Tannen 1994; James and Clarke, 1993). Five, these studies tend to exaggerate the differences, while ignoring overlaps and similarities.

Though now these two approaches are not seen as popular as they used to be in the mid-seventeen and eighteen centuries and they have received much criticism by postmodernist researchers, no one can deny their enormous contribution to the understanding of the complicated gender issues in relation to language.

\subsection{The post-modernist approach}

The 1980s and 1990s saw the emergence of a new approach to language and gender studies, namely 'post-modernist approach' (Gibbon, 1999:11), as a result of the influence of post-structuralism. However, there does not seem to be a consensus in the naming of this approach; hence, some other authors call this approach 'performance approach' (Cameron and Coates, 1989), 'poststructuralist approach' (Baxter, 2003) or 'third-wave feminist linguistics' (Mill, 2008). Underlying the difference in referring to this approach is the choice of referring terms like post-modernism or post-structuralism. As commonly understood, post-modernism refers to the general philosophical movement incorporating all fields of knowledge such as art, architecture, and also feminism. Post-modernism is best characterized by a sense of skepticism towards all universal causes, its questioning of what 'true' or 'real' knowledge is and its loss of certainty about all absolutes (Baxter, 2003). As a branch of post-modernism, post-structuralism has a particular interest in language as a site for the construction and contestation of social meanings. So in the domain of feminism as a field of social knowledge, the term postmodernist seems to be more appropriate and in reality, the third way feminism (arising in the 1980s) is termed post-modernist feminism (following and developing from modernist feminism or the second way feminism in the 1960s and 1970s). However, when talking about the discursive approach of feminist studies, 'post-structuralist' is the more appropriate choice as post-structuralism is the theory particularly related to language study. Cameron and Mills chose to avoid using both terms in naming this approach. While Cameron highlights just one aspect of post-modernism, which is 'performance' originated from the idea of 'performativity' by Butler (1990), Mills prefers the chronological order-based name of feminism, which was the third wave feminism.

An example of studies illustrating the postmodernist approach is Deborah Cameron's Performing Gender Identity (Coates, 1998). In this work, she studied a conversation of a group of male students to show how gender was performed through talks, drawing on Butler's notion of performativity. The conversation was recorded while they were watching sports. Those boys talked about topics of sports, women, alcohol and other boys. Cameron argued that for men, it was as important to demonstrate that they were not gay as they were not women. That meant they performed heterosexual masculinity. Cameron showed how the talk of these men involves several features normally associated with 'cooperative' women's talk such as hedges, overlapping speech, but it also displayed more competitive features - two speakers dominated the talk, and speakers 
vied for the floor. She argued that competition and cooperation as styles of talking could not be simplistically attributed to one gender or the other (like what people had claimed in the other two approaches).

While the dominance and difference approaches, seen as influenced by the second wave feminism, assume that gender pre-exists interaction and affects the way that interaction develops, post-modernist approach, influenced by the third wave feminism and post-structuralism, sees gender as constructed and the way that participants perform in conversations bring about their gender identity (Mills, 2008). The category of gender is clearly distinguished from the category of sex, in which the former should be socially developed and the latter is biologically dependent. While sex characteristic of a person is determined at birth as either female or male, and is more or less fixed, gender is fluid and keeps changing in the process of a person's development and socialization. Gender should be seen as a continuum towards femininity and masculinity, and gender is highly culturedependent.

This new approach turns to the role of discourse generally seen as social practice, which reflects and creates how we see the world including assumptions about gender and gender inequalities. This perspective assumes that language does not simply reflect social reality but it is also constitutive of such reality. Language is constitutive rather than indexical (language simply to encode reality); then, it has the potential to help establish and maintain social and power relations, values and identities (Litosseliti, 2006). Hence, research in the post-modernist approach focuses on language used by men and women (to construct their own gender identities) and also, language to talk about them (to discursively construct gender relations, gender assumptions, etc.)
The shift in theorization of gender in relation to language entails a shift in the research methodology. While studies in the earlier two approaches were mostly done with introspection and observation (Lakoff, 1975; Spender, 1980), sociolinguistic survey and conversation analysis (Zimerman and West,1975; Coates, 1998), Litosseliti (2006) noted that current thinking led to an emphasis on discourse analysis and critical discourse analysis as valuable frameworks for exploring a range of text types for their contribution to the construction of gender. Since 'many proposals and basic assumptions of feminist linguistics relate to and overlap with principles of critical linguistics and critical discourse analysis' (Wodak, 1997 as quoted in Sunderland, 2004: 59) the marriage between feminism and CDA seems reasonable and inevitable. Sunderland also stated that CDA was theoretically well placed to seek and identify gendered discourses of a damaging kind. While CDA aims to show non-obvious ways in which language is involved in social relations of power and domination, feminist linguistics seeks to unveil the unequal gender relation prevalent but hidden in discourse. In fact, many feminist linguists have used CDA fruitfully in their feminist research and Lazar (2005) was the first book to explicitly bring together achievement of this theoretical approach (Sunderland, 2004).

Some examples of studies on gendered discourses include Nguyen (2011) in which she explored how Vietnamese women were represented by the print media on the International Women's Day. What she found was a number of gender assumptions that disadvantaged women in many counts, in which the 'double role' ideology prominently was argued as a social practice of a damaging kind. She challenged the gender-role assumptions and opined that the media was disseminating ideologies that went against 
political efforts for gender equality. In the context of Hong Kong, Lee (2004) examined news discourse about successful female officials. The general finding of the study was that in the media discourse, female officials' career success did not prevent them from being good mothers, wives and daughters. Such a representation suggested that a woman could take care of her different roles by 'keeping the balance' and using time efficiently. The implication of such positive coverage was that if some women could make it, then all women could, and if some of them could not, then it was their fault. Another example is Lazar (2005b), in which she investigated the hegemonic forms of masculinity as revealed in a national "Family Life" advertising campaign in Singapore. The author found two contending discourses: one of egalitarian gender relations and the other of conservative gender relations. In the first place, Singaporean men were depicted as equal parents in taking care of the children. They were also caring, sensitive, nurturing, which was far different from the stereotype of men as 'authoritarian' or 'distant breadwinner'. However, there was still a gender differentiation in the roles of the mother and father in the domestic sphere. Also, when father's care was depicted, it was just limited to fun and physical play. Other mundane aspects of care such as towel-drying children and cooking for the family fell on mothers.

\subsection{Current topics for debates}

Recent research has revealed a proposal that since there are differences among groups of men as well as groups of women, less emphasis is now put on the differences between men and women as homogeneous groups. The aims of current studies are moving towards exploring how different social categories cut across the category of sex to form different groups of men and women and how the identity of these groups are being constructed through their own language use and through particular discourses that talk about them. In IGALA 2016 (International Gender and Language Association - the best known biannual conference for language and gender studies), various presented papers were seen investigating the (problematic or disadvantaging) discursive construction of the homosexual population. In this case, the category of sexuality cuts across the category of gender to form groups of gays, lesbians and straight men and women. For example, Sunderland (IGALA 9, 2016), in Language textbooks and sexual identity: Representation and consumption, opined that students would not identify with the relentless heteronormative textbook portrayals of mum-dad families and boy-girl romance. However, sexuality representation is complex and no one expects equal numbers of gay and straight characters; in many contexts, the only possible textual representation of sexuality is heterosexuality, so she proposes that teachers may be able to interrogate hetero-normative texts, opening up previously closed readings. An interesting study by Man Yu (IGALA 9, 2016) was on the representation of 'leftover women' in the Hong Kong reality television show. 'Leftover' women in this study were defined as single women in their $30 \mathrm{~s}-40 \mathrm{~s}$, and she found that the programme framed the participants finding partners as a battle/ race and characterized them as different types of women. This shaped views on different types of women vis-à-vis their marriageability. Other studies in this trend include Lazar's (IGALA 9, 2016) on the Pink dot campaign in Singapore, Rowlett's (IGALA 9, 2016) on same sex relationships and the practice of 'sponsorship' in Cambodia, and Cooke's (IGALA 9, 2016) on queering ESOL towards a cultural politics of LGBT in the ESOL classroom. Apparently, in exploring gender relations and gender assumptions 
in discourse, the current trend is towards focusing on sub-groups of men and women in the society. More of such studies can normally be found in Gender and Language journal and Discourse and Society journal.

\section{Conclusion}

Research in language and gender has been thriving nonstop and has been experiencing different debates as presented in this study. The debates can never be said to be over, though the trend has been moving from seeing language as reflection of gender towards language as construction of gender, and from seeing men and women as two homogenous groups to focusing on different groups of men or women. People have also started to move from discourse produced by men and women to discourse about them. These moves have been enabled, influenced and supported by emerging philosophical as well as linguistic theories. Researchers who are interested in language and gender studies, hence, need to see where and how they wish to position their studies in this 'language and gender debate map'.

\section{References}

Baxter, J. (2003). Positioning gender in discourse - A feminist methodology. New York: Palgrave Macmillan.

Beasley, C. (1999). What is feminism? An introduction to feminist theory. London: SAGE publications.

Butler, R. (1990). Gender trouble: Feminism and the subversion of identity. New York: Routledge.

Cameron, D. (1992) $2^{\text {nd }}$ ed. Feminism and linguistic theory. Basingstoke, Hants: Macmillan.

Cameron, D. and Coates, J. (eds.) (1989). Women in their speech communities. London: Longman.

Coates, J. (1998). Language and gender - A reader. Oxford: Blackwell Publishers Ltd.

Defrancisco, V. (1991). The sounds of silence: How men silence women in marital relations. Discourse and society 2(4): 413-423.

Gibbon, M. (1999). Feminist perspectives on language. New York: Longman.

Gray, J. (1992). Men are from Mars, women are from Venus. London: Harper Element.

IGALA 9 (2016) Program booklet, available at: https:// www.scribd.com/doc/315582344/IGALA9-

\section{Programme-Booklet}

James, D. and Clark, S. (1993). Women, men and interruptions: A critical review. In D. Tannen, (ed.), Gender and conversational interaction (pp 231280). New York: Oxford University Press Inc.

Lakoff, R. (1975). Language and woman's place. New York: Harper \& Row.

Lazar, M. M. (2005a). Feminist Critical Discourse Analysis. New York: Palgrave Macmillan.

Lazar, M. M. (2005b). Performing State Fatherhood: The Remaking of Hegemony. In M. M. Lazar (ed.), Feminist Critical Discourse Analysis (pp. 139-163). New York: Palgrave Macmillan.

Lee, F. L. F. (2004). Constructing perfect women: the portrayal of female officials in Hong Kong newspapers. Media, Culture \& Society, 26(2), 207 -225 .

Litosseliti, L. (2006). Gender and language: Theory and practice. New York: Oxford University Press.

Mills, S. (2008). Language and sexism. New York: Cambridge University Press.

Nguyễn Thị Thu Hà (2011). Gender ideologies in Vietnamese printed media. In D. Majstorovic \& I. Lassen (eds.), Living with Patriarchy (pp. 195-218). Amsterdam: John Benjamins.

Spender, D. (1980). Man made language. London: Routledge.

Sunderland, J. (2004). Gendered discourses. New York: Palgrave Macmillan.

Tannen, D. (1985). Cross-cultural communication. Handbook of discourse analysis (4) 203 - 215.

Tannen, D. (1986). That's not what I meant! London: Random House.

Tannen, D. (1990). You just don't understand. London: Random House.

Tannen, D. (1994). Gender and discourse. London: Oxford University Press.

West, C. (1984). When the doctor is a lady: Power status and gender in physician - patient encounters. In J. Coates (ed.), Language and gender: A reader (pp. 396-412). Oxford, Massachusetts: Blackwell Publishers Inc.

Wodak, R. (1997). Gender and discourse. London: Sage Publication.

Woods, N. (1989). Talking shop: sex and status as determinants of floor apportionment in a working setting. In J. Coates, and D. Cameron, (eds.), Women in their speech communities (141-157). Longman.

Zimmerman, D \& West, C. (1975). Sex roles, interruptions and silences in conversation. In B. Thorn \& N. Henley (eds.), Language and sex: difference and dominance (pp. 105-129). Rowley, Mass.: Newbury House. 


\title{
NGÔN NGŨ๋ VÀ GIỚI: \\ CÁC HƯớNG TIẾP CẬN TÙ TRƯớC ĐẾN NAY
}

\author{
Nguyễn Thị Thu Hà \\ Khoa Ngôn ngũ và Văn hóa các nước nói tiếng Anh, Trường Đại học Ngoại ngũu, ĐHQGHN, \\ Phạm Văn Đồng, Cầu Giáy, Hà Nội, Việt Nam
}

Tóm tắt: Nghiên cứu này trình bày và phân tích các hướng tiếp cận khác nhau trong lĩnh vực ngôn ngữ và giới, một lĩnh vực thuộc ngôn ngữ học bắt đầu hình thành từ những năm đầu của thập kỷ 70 của thế kỷ trước. Các đường hướng thống trị giới, khác biệt giới và hậu hiện đại được phân tích và trình bày theo trình tự thời gian cùng với những nghiên cứu điển hình nhằm minh họa cho những đặc điểm của từng đường hướng. Ngoài ra, tác giả cũng đưa ra các nhận định, so sánh đặc điểm của các đường hướng để người đọc có thể hiểu rõ hơn về những đường hướng này. Bài báo cũng nhấn mạnh những chủ đề và những tranh luận hiện nay trong lĩnh vực ngôn ngữ và giới được thể hiện trong các hội thảo ngôn ngữ và giới (IGALA) gần đây nhất.

Tù khóa: ngôn ngữ và giới, khác biệt giới, thống trị giới, chủ nghĩa hậu cấu trúc, ngôn ngữ và $\mathrm{xu}$ hướng tình dục 